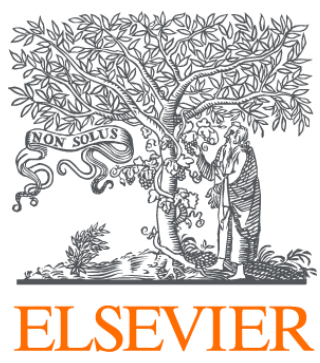

Since January 2020 Elsevier has created a COVID-19 resource centre with free information in English and Mandarin on the novel coronavirus COVID-

19. The COVID-19 resource centre is hosted on Elsevier Connect, the company's public news and information website.

Elsevier hereby grants permission to make all its COVID-19-related research that is available on the COVID-19 resource centre - including this research content - immediately available in PubMed Central and other publicly funded repositories, such as the WHO COVID database with rights for unrestricted research re-use and analyses in any form or by any means with acknowledgement of the original source. These permissions are granted for free by Elsevier for as long as the COVID-19 resource centre remains active. 


\section{Journal Pre-proof}

COVID-19 infection in patients with mast cell disorders including mastocytosis does not impact mast cell activation symptoms

Matthew P. Giannetti, MD, Emily Weller, Iván Alvarez-Twose, MD PhD, Inés Torrado, MD, Patrizia Bonadonna, MD, Roberta Zanotti, MD, Daniel F. Dwyer, PhD, Dinah

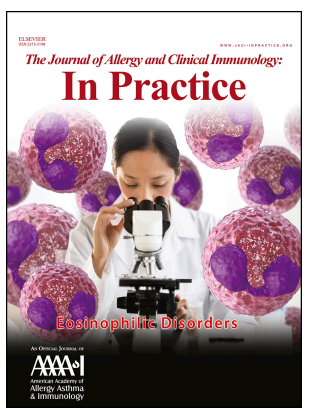
Foer, MD, Cem Akin, MD PhD, Karin Hartmann, MD, Tiago Azenha Rama, DMD, MD, Wolfgang R. Sperr, MD, Peter Valent, MD, Cristina Teodosio, PhD, Alberto Orfao, MD $\mathrm{PhD}$, Mariana Castells, MD PhD

PII: S2213-2198(21)00203-8

DOI: https://doi.org/10.1016/j.jaip.2021.02.023

Reference: JAIP 3448

To appear in: The Journal of Allergy and Clinical Immunology: In Practice

Received Date: 15 December 2020

Revised Date: 18 January 2021

Accepted Date: 9 February 2021

Please cite this article as: Giannetti MP, Weller E, Alvarez-Twose I, Torrado I, Bonadonna P, Zanotti R, Dwyer DF, Foer D, Akin C, Hartmann K, Rama TA, Sperr WR, Valent P, Teodosio C, Orfao A, Castells M, COVID-19 infection in patients with mast cell disorders including mastocytosis does not impact mast cell activation symptoms, The Journal of Allergy and Clinical Immunology: In Practice (2021), doi: https:// doi.org/10.1016/j.jaip.2021.02.023.

This is a PDF file of an article that has undergone enhancements after acceptance, such as the addition of a cover page and metadata, and formatting for readability, but it is not yet the definitive version of record. This version will undergo additional copyediting, typesetting and review before it is published in its final form, but we are providing this version to give early visibility of the article. Please note that, during the production process, errors may be discovered which could affect the content, and all legal disclaimers that apply to the journal pertain.

(C) 2021 Published by Elsevier Inc. on behalf of the American Academy of Allergy, Asthma \& Immunology 


\section{COVID-19 infection in patients with mast cell disorders including mastocytosis does not impact mast cell activation symptoms}

\section{Authors:}

Matthew P. Giannetti MD, ${ }^{1,2}$ Emily Weller, ${ }^{1}$ Iván Alvarez-Twose MD PhD,${ }^{3}$ Inés Torrado MD ${ }^{3}$ Patrizia Bonadonna MD,${ }^{4}$ Roberta Zanotti MD ${ }^{5}$ Daniel F. Dwyer PhD ${ }^{1,2}$ Dinah Foer MD,${ }^{1,2}$ Cem Akin MD PhD ${ }^{6}$, Karin Hartmann MD, ${ }^{7}$ Tiago Azenha Rama, DMD, MD ${ }^{8,9}$ Wolfgang R. Sperr MD,${ }^{10}$ Peter Valent MD ${ }^{10}$ Cristina Teodosio $\mathrm{PhD},{ }^{11}$ Alberto Orfao MD PhD,${ }^{12}$ Mariana Castells MD PhD $\mathrm{Ph}^{1,2}$

${ }^{1}$ Division of Allergy and Clinical Immunology, Brigham and Women's Hospital, Boston, MA; ${ }^{2}$ Harvard Medical School, Boston, MA; ${ }^{3}$ Instituto de Estudios de Mastocitosis de Castilla-La Mancha (CLMast) - Spanish Reference Center for Mastocytosis, Hospital Virgen del Valle, Complejo Hospitalario de Toledo, Toledo, Spain; ${ }^{4}$ Allergy Unit, Verona University Hospital, Verona, Italy; ${ }^{5}$ Department of Medicine, Section of Hematology, Verona, Italy ${ }^{6}$ Division of Allergy and Immunology, University of Michigan, Ann Arbor, MI; ${ }^{7}$ Division of Allergy, University Hospital Basel and University Basel, Basel, Switzerland; ${ }^{8}$ Serviço de Imunoalergologia, Centro Hospitalar Universitário de São João, Porto, Portugal, ${ }^{9}$ Serviço de Imunologia Básica e Clínica, Departamento de Patologia, Faculdade de Medicina da Universidade do Porto, Porto, Portugal; ${ }^{10}$ Department of Internal Medicine I, Division of Hematology and Hemostaseology and Ludwig Boltzmann Institute for Hematology and Oncology, Medical University of Vienna, Vienna, Austria; ${ }^{11}$ Department of Immunology, Leiden Medical Center, Leiden, The Netherlands; ${ }^{12}$ Cancer Translational Research Program, Cancer Research Center (IBMCC-CSIC/USAL), Department of Medicine, Sequencing Service and Cytometry Service (NUCLEUS), University of Salamanca (USAL), Biomedical Research Institute of Salamanca (IBSAL) and CIBERONC (Salamanca, Spain).

\section{Corresponding Author:}

Mariana Castells, MD PhD

Division of Allergy and Clinical Immunology

Brigham and Women's Hospital

60 Fenwood Road

Hale building for transformational medicine, $5^{\text {th }}$ floor

Boston, MA 02132

Tel: 617-732-9850

Email: mcastells@bwh.harvard.edu

\section{Conflict of Interest Disclosures:}

Matthew Giannetti, Cem Akin and Mariana Castells receive funding from Blueprint Medicines. Karin Hartmann received research funding from Euroimmun and lecture or consultancy fees from Allergopharma, ALK-Abello, Blueprint, Deciphera, Menarini, Novartis and Takeda.

All other authors declare no conflicts of interest. 


\section{Methods:}

This study was conducted under Mass General Brigham IRB protocols 2012P002481 and 2018P000122. All data was gathered from retrospective electronic medical record review. Data on demographics, level of care, laboratory results, and mast cell activation symptoms were collected. Assessment of mast cell activation symptoms was completed by the treating physician. 

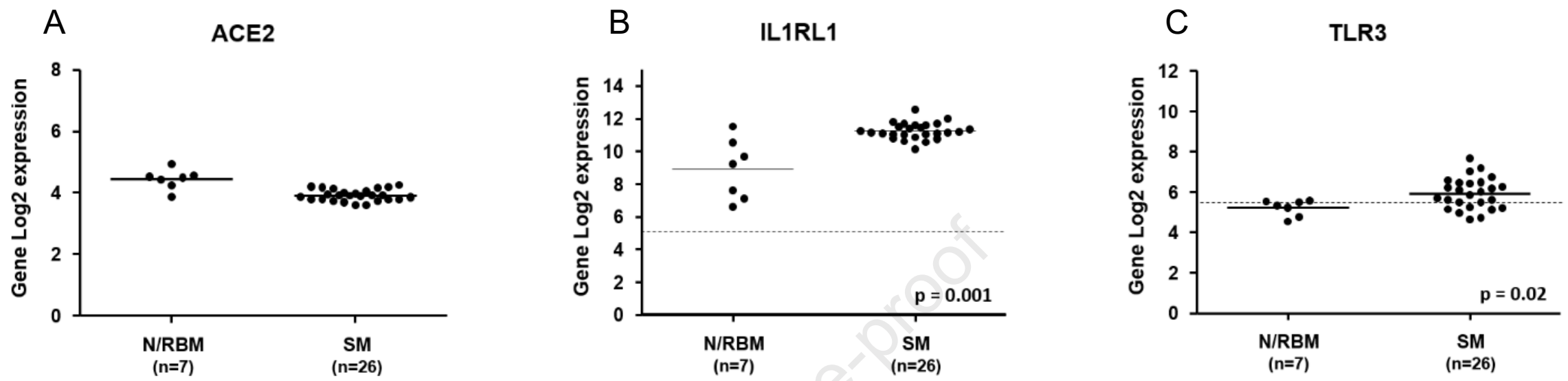

Figure 1 


\title{
COVID-19 infection in patients with mast cell disorders including mastocytosis does not impact mast cell activation symptoms
}

\section{Authors:}

Matthew P. Giannetti MD, ${ }^{1,2}$ Emily Weller BA, ${ }^{1}$ Iván Alvarez-Twose MD PhD, ${ }^{3}$ Inés Torrado MD, ${ }^{3}$ Patrizia Bonadonna MD,${ }^{4}$ Roberta Zanotti MD,${ }^{5}$ Daniel F. Dwyer PhD, ${ }^{1,2}$ Dinah Foer MD, ${ }^{1,2}$ Cem Akin MD PhD ${ }^{6}$, Karin Hartmann MD, ${ }^{7}$ Tiago Azenha Rama, DMD, MD ${ }^{8,9}$ Wolfgang R. Sperr MD,${ }^{10}$ Peter Valent MD ${ }^{10}$ Cristina Teodosio PhD,${ }^{11}$ Alberto Orfao MD PhD,${ }^{12}$ Mariana Castells MD $\mathrm{PhD}^{1,2}$

${ }^{1}$ Division of Allergy and Clinical Immunology, Brigham and Women's Hospital, Boston, MA; ${ }^{2}$ Harvard Medical School, Boston, MA; ${ }^{3}$ Instituto de Estudios de Mastocitosis de Castilla-La Mancha (CLMast) - Spanish Reference Center for Mastocytosis, Hospital Virgen del Valle, Complejo Hospitalario de Toledo, Toledo, Spain; ${ }^{4}$ Allergy Unit, Verona University Hospital, Verona, Italy; ${ }^{5}$ Department of Medicine, Section of Hematology, Verona, Italy ${ }^{6}$ Division of Allergy and Immunology, University of Michigan, Ann Arbor, MI; ${ }^{7}$ Division of Allergy, University Hospital Basel and University Basel, Basel, Switzerland; ${ }^{8}$ Serviço de Imunoalergologia, Centro Hospitalar Universitário de São João, Porto, Portugal, ${ }^{9}$ Serviço de Imunologia Básica e Clínica, Departamento de Patologia, Faculdade de Medicina da Universidade do Porto, Porto, Portugal; ${ }^{10}$ Department of Internal Medicine I, Division of Hematology and Hemostaseology and Ludwig Boltzmann Institute for Hematology and Oncology, Medical University of Vienna, Vienna, Austria; ${ }^{11}$ Department of Immunology, Leiden Medical Center, Leiden, The Netherlands; ${ }^{12}$ Cancer Translational Research Program, Cancer Research Center (IBMCC-CSIC/USAL), Department of Medicine, Sequencing Service and Cytometry Service (NUCLEUS), University of Salamanca (USAL), Biomedical Research Institute of Salamanca (IBSAL) and CIBERONC (Salamanca, Spain).

\author{
Corresponding Author: \\ Mariana Castells, MD PhD \\ Division of Allergy and Clinical Immunology \\ Brigham and Women's Hospital \\ 60 Fenwood Road \\ Hale building for transformational medicine, $5^{\text {th }}$ floor \\ Boston, MA 02132 \\ Tel: 617-732-9850 \\ Email: mcastells@bwh.harvard.edu
}

\section{Conflict of Interest Disclosures:}

Matthew Giannetti, Cem Akin and Mariana Castells receive funding from Blueprint Medicines. Karin Hartmann received research funding from Euroimmun and lecture or consultancy fees from Allergopharma, ALK-Abello, Blueprint, Deciphera, Menarini, Novartis and Takeda.

All other authors declare no conflicts of interest.

Text word count: 1145 


\section{Clinical Implications}

52 COVID-19 mortality in patients with mast cell disorders is comparable to the general population.

53 Bone marrow mast cells lack ACE-2 receptors. These data argue against clinically significant

54 mast cell activation during COVID-19 infection.

55

56 
SARS-CoV-2 is a novel coronavirus responsible for the clinical syndrome COVID-19. This virus was initially recognized in December 2019 in Wuhan, China and has since spread leading to a global pandemic. Mast cells (MCs) are tissue resident innate immune cells that play a pathobiologic role in a range of diseases, such as asthma, rhinitis and food allergy and MC activation disorders. MC activation leads to the release of inflammatory mediators, including tryptase and several cytokines such as interleukin (IL)-6. MCs are often active participants in propagation of inflammation during viral infection.(1) Reports of serious COVID-19 infections have identified IL-6, TNF and IL-1 $\beta$ as hallmarks of cytokine storm leading to severe outcomes.(2) MCs are a source of IL-6 and other proinflammatory mediators, leading to the possibility of MCs directly contributing to the severity of SARS-CoV-2 infection. However, studies involving allergic asthma, a disease associated with increased lung MC numbers and activation, have not shown an increased risk for severe outcomes.(3) Thus, the role of MCs in SARS-CoV-2 infection remains unknown.

Symptoms of SARS-CoV-2 infection include cough, fever, dyspnea, and diarrhea. These overlap with some clinical symptoms of MC activation which also include urticaria, flushing, and hypotension, among other symptoms. Because mast cells have been shown to activate during viral infection, increased severity of SARS-CoV-2 infection in patients with MC disorders is possible.(4) Here we report the impact of SARS-CoV-2 infection in 28 patients with clonal $(n=24)$ MC disorders including mastocytosis and in patients with clinical symptoms of MC activation and elevated baseline serum tryptase with $(n=4)$. This cohort of patients did not have increased COVID-19 mortality and lacked clinical symptoms of MC activation.

\section{Twenty-eight patients with mast cell disorders and confirmed SARS-CoV-2 infection were} identified by EHR review, of which $57 \%$ were female and average age was 50 years. The average baseline serum tryptase was $40.5 \mathrm{ng} / \mathrm{mL}$ (range 5.9-140 ng/mL). Average total serum IgE was $28.9 \mathrm{IU} / \mathrm{ml}$ (range: $2.0-159 \mathrm{IU} / \mathrm{ml}$ ), data not shown. Seventeen patients had indolent systemic mastocytosis (ISM) diagnosed according to WHO criteria.(5) Five patients had cutaneous mastocytosis and two had systemic mastocytosis with an associated hematologic neoplasm (SM-AHN). Four patients had elevated baseline serum tryptase and symptoms of MC activation. Subjects were included on the basis of a positive SARS-CoV-2 PCR test during acute 
infection in 23/28 (82\%) and/or antibody test after convalescence 5/28 (18\%). Baseline characteristics are described in Table 1.

Most patients had a mild course of COVID-19. Inpatient hospitalization was required in 12/28 (43\%). One patient required intensive care unit admission for hypoxia; none required full mechanical ventilation. One patient with ISM died from SARS-CoV-2-associated pneumonia. His medical history was notable for multiple comorbidities that placed him at high risk for poor outcomes including coronary artery disease with three stents, aortic valve replacement, atrial flutter, obstructive sleep apnea and chronic obstructive pulmonary disease. Regarding COVID19 directed therapy, 8/28 (28\%) were treated with hydroxychloroquine. Five were treated with antiretroviral therapy (ritonavir/lopinavir). One patient received systemic steroids. None was treated with remdesivir or tocilizumab. One patient was pregnant during the course of infection and delivered a healthy baby without complications. The longest reported symptom duration was greater than 2 months and the shortest was 7 days, with an average symptom duration of 29 days.

In addition to symptoms of viral upper respiratory tract infection (URI), we recorded symptoms of MC activation. Among the 28 patients, no patient endorsed MC activation symptoms during viral illness. Specifically, none reported infection-associated urticaria or anaphylaxis. Several noted an improvement in baseline pruritus, bloating, and diarrhea. These MC activation symptoms recurred after convalescence from COVID-19.

Infection with SARS-CoV-2 can induce MC activation and symptoms such as urticaria, flushing, diarrhea and hypotension(3), especially in patients with MC disorders. The absence of clinical MC activation in all 28 patients with COVID-19 is a striking finding. Lack of MC activation suggests the absence of direct MC infection, lack of secondary MC activation, or active MC suppression. Notably, SARS-CoV-2 has been reported to suppress other innate immune system pathways such as type-I interferon, suggesting the potential for a similar suppressive mechanism with MC activation.(6)

To further understand the lack of MC activation during SARS-CoV-2 infection and explain this unexpected clinical observation, we examined retrospective gene array data from highly purified 
bone marrow (BM) MCs from patients with mastocytosis and healthy control subjects.(7) BMMC gene expression data was obtained in 2013 and did not include any patients reported in this study. BM-resident MCs did not express detectable levels of ACE2, consistent with reports that oral mucosa MCs also lack ACE2, which likely precludes direct infection of the MC.(8) MCs from mastocytosis patients did express elevated levels of TLR3 and ILIRL1, encoding the IL33 receptor ST2, relative to healthy controls, suggesting potential modalities for MC activation in response to viral infections (Figure 1).

Absence of clinical evidence for MC activation during COVID-19 has been observed in other conditions driven by MC activation, most notably in asthma. Current evidence suggest that SARS-Cov-2 infection does not cause asthma exacerbations and is not associated with worse outcomes in asthmatic patients.(9) Further, Th2-high asthma is known to be driven by MCmediated inflammation, and this condition may not increase severity of COVID-19 disease. ${ }^{5}$ This is in stark contrast to other viral URIs, which are common triggers for asthma exacerbation. Our study suggests that, in patients with mast cell disorders, MC activation does not play a major role in the inflammatory response to SARS-CoV-2. Mast cell mediators during acute infection was available in only one patient and was unchanged from baseline, suggesting lack of acute MC activation in this patient.

The hospitalization rate in our cohort is higher than current United States rates in the general population; however, this may be due to international variation across sites, particularly in Spain and Italy during the early months of the pandemic. It is also possible patients seek additional care and/or are prophylactically hospitalized given the mast cell disorder comorbidity. The incidence of asymptomatic MC activation patients infected with COVID-19 is unknown, and larger studies are needed to validate our observations. Our study is also limited by patient recall of symptoms, which can be subjective. Due to the nature of COVID-19, direct observation of patients and collection of empiric data such as mast cell mediators was not practical for most patients. It is also possible that medications (antihistamines, receptor antagonists, etc) may have impacted mast cell activation symptoms and/or COVID-19 disease severity. 
149 To our knowledge this is the first report detailing the clinical course and outcomes of patients

150 with MC disorders and confirmed SARS-CoV-2 infection. Our international cohort spans

151 pediatric and adult patients with clonal and nonclonal MC disorders. We did not observe clinical

152 evidence of SARS-CoV-2-induced MC activation. Based on these data, we hypothesize that

153 SARS-CoV-2 infection may not cause direct or indirect MC activation. Patients with MC

154 disorders have mortality outcomes similar to the general population when infected with SARS-

155 CoV-2.

156 
157

158 Acknowledgements:

159 We thank Liqin Wang $\mathrm{PhD}$ for assistance with data collection.

160

161

162 
163

164

165

166

167

168

169

170

171

172

173

174

175

176

177

178

179

180

181

182

183

184

185

186

187

188

189

190

References:

1. Graham AC, Temple RM, Obar JJ. Mast cells and influenza A virus: Association with allergic responses and beyond. Front Immunol. 2015;6(MAY):1-12.

2. Buszko M, Park JH, Verthelyi D, Sen R, Young HA, Rosenberg AS. The dynamic changes in cytokine responses in COVID-19: a snapshot of the current state of knowledge. Nat Immunol. 2020;21(10):1146-51.

3. Wang D, Hu B, Hu C, Zhu F, Liu X, Zhang J, et al. Clinical Characteristics of 138 Hospitalized Patients with 2019 Novel Coronavirus-Infected Pneumonia in Wuhan, China. JAMA - J Am Med Assoc. 2020;323(11):1061-9.

4. Valent P, Akin C, Bonadonna P, Brockow K, Niedoszytko M, Nedoszytko B, et al. Risk and Management of Patients with Mastocytosis and MCAS in the SARS-CoV-2 (COVID-19) Pandemic: Expert Opinions *. J Allergy Clin Immunol [Internet]. 2020;146(2):300-6. Available from: https://doi.org/10.1016/j.jaci.2020.06.009

5. Valent P, Akin C, Metcalfe DD. Review Article Mastocytosis : 2016 updated WHO classi fi cation and novel emerging treatment concepts. Blood. 2017;129(11):1420-8.

6. Lei X, Dong X, Ma R, Wang W, Xiao X, Tian Z, et al. Activation and evasion of type I interferon responses by SARS-CoV-2. Nat Commun. 2020;11(1):1-12.

7. Teodosio C, García-Montero AC, Jara-Acevedo M, Sánchez-Muñoz L, Pedreira CE, ÁlvarezTwose I, et al. Gene expression profile of highly purified bone marrow mast cells in systemic mastocytosis. J Allergy Clin Immunol. 2013;131(4).

8. Xu H, Zhong L, Deng J, Peng J, Dan H, Zeng X, et al. High expression of ACE2 receptor of 2019$\mathrm{nCoV}$ on the epithelial cells of oral mucosa. Int J Oral Sci [Internet]. 2020;12(1):1-5. Available from: http://dx.doi.org/10.1038/s41368-020-0074-x

9. Grandbastien M, Piotin A, Godet J, Abessolo-Amougou I, Ederlé C, Enache I, et al. SARS-CoV-2 pneumonia in hospitalized asthmatic patients did not induce severe exacerbation. J Allergy Clin Immunol Pract. 2020;1-8. 
191 Table I: Baseline characteristics of patients and SARS-CoV-2 infection data and outcome. ${ }^{1}$

\begin{tabular}{|c|c|c|c|c|c|c|c|c|c|c|c|}
\hline Patient & Age & Sex & $\begin{array}{l}\text { Mast Cell } \\
\text { Disorder }\end{array}$ & $\begin{array}{l}\text { Baseline } \\
\text { Tryptase } \\
\text { (ng/mL) }\end{array}$ & $\begin{array}{l}\text { KIT } \\
\text { D816V }\end{array}$ & $\begin{array}{l}\text { SARS- } \\
\text { CoV-2 } \\
\text { Diagnosis }\end{array}$ & $\begin{array}{l}\text { Viral } \\
\text { Symptoms }\end{array}$ & $\begin{array}{l}\begin{array}{l}\text { Level } \\
\text { of } \\
\text { Care }\end{array} \\
\end{array}$ & $\begin{array}{l}\text { Oxygen } \\
\text { Requirement }\end{array}$ & $\begin{array}{l}\text { MCAS } \\
\text { Symptoms/ } \\
\text { Anaphylaxis }\end{array}$ & Outcome \\
\hline 1 & 52 & $\mathrm{M}$ & ISM & 140.0 & - & PCR & $\begin{array}{l}\text { R, C, F, M, } \\
\text { GI }\end{array}$ & Hosp & LF & $\mathrm{N}$ & recovery \\
\hline 2 & 50 & $\mathrm{M}$ & ISM & 28.8 & + & PCR, IgG & $\begin{array}{l}\mathrm{R}, \mathrm{C}, \mathrm{F}, \mathrm{GI}, \\
\mathrm{T}, \mathrm{N}\end{array}$ & Hosp & $\mathrm{N}$ & $\mathrm{N}$ & recovery \\
\hline 3 & 77 & $\mathrm{~F}$ & ISM & 94.2 & + & PCR & $\mathrm{R}, \mathrm{C}, \mathrm{F}, \mathrm{M}$ & Hosp & LF & $\mathrm{N}$ & recovery \\
\hline 4 & 65 & $\mathrm{~F}$ & ISM & 62.9 & + & PCR & $\mathrm{R}, \mathrm{C}, \mathrm{M}$ & Hosp & LF & $\mathrm{N}$ & recovery \\
\hline 5 & 65 & $\mathrm{~F}$ & ISM & 6.9 & - & PCR & $\mathrm{R}, \mathrm{C}, \mathrm{F}$ & ICU & $\mathrm{HF}$ & $\mathrm{N}$ & recovery \\
\hline 6 & 38 & $\mathrm{~F}$ & ISM & 66.3 & + & PCR & $\mathrm{F}$ & Home & $\mathrm{N}$ & $\mathrm{N}$ & recovery \\
\hline 7 & 53 & $\mathrm{M}$ & ISM & 23.8 & + & PCR & none & Home & $\mathrm{N}$ & $\mathrm{N}$ & recovery \\
\hline 8 & 40 & $\mathrm{~F}$ & ISM+ & 18.3 & - & PCR & $\mathrm{A}, \mathrm{H}, \mathrm{C}, \mathrm{M}$ & Home & $\mathrm{N}$ & $\mathrm{N}$ & $\begin{array}{l}\text { *on } \\
\text { going }\end{array}$ \\
\hline 9 & 54 & $\mathrm{~F}$ & ISM+ & 9.61 & - & PCR & $\begin{array}{l}\text { R, C, F, M, } \\
\text { A, GI, H }\end{array}$ & Hosp & $\mathrm{N}$ & $\mathrm{N}$ & recovery \\
\hline 10 & 55 & $\mathrm{~F}$ & ISM + & 97.6 & + & PCR & A & Home & $\mathrm{N}$ & $\mathrm{N}$ & recovery \\
\hline 11 & 54 & $\mathrm{~F}$ & ISM + & 101.0 & + & PCR & $\mathrm{C}, \mathrm{T}, \mathrm{N}, \mathrm{D}$ & Home & $\mathrm{N}$ & $\mathrm{N}$ & recovery \\
\hline 12 & 52 & $\mathrm{~F}$ & ISM + & 45.0 & + & IgM / IgG & $\mathrm{A}, \mathrm{D}$ & Home & $\mathrm{N}$ & $\mathrm{N}$ & recovery \\
\hline 13 & 56 & $\mathrm{~F}$ & ISM + & 5.9 & + & $\mathrm{IgG}$ & $\mathrm{R}, \mathrm{M}, \mathrm{H}, \mathrm{GI}$ & Hosp & $\mathrm{N}$ & $\mathrm{N}$ & recovery \\
\hline 14 & 61 & $\mathrm{M}$ & ISM + & 93.9 & + & PCR, IgG & $\mathrm{C}, \mathrm{M}, \mathrm{F}, \mathrm{GI}$ & Home & $\mathrm{N}$ & $\mathrm{N}$ & recovery \\
\hline 15 & 49 & M & ISM + & 25.8 & + & $\mathrm{IgG}$ & $\mathrm{C}, \mathrm{F}, \mathrm{R}, \mathrm{H}$ & Hosp & LF & $\mathrm{N}$ & recovery \\
\hline 16 & 72 & $\mathrm{M}$ & ISM + & 55.1 & + & PCR & $\mathrm{R}, \mathrm{C}, \mathrm{F}, \mathrm{M}, \mathrm{T}$ & Hosp & LF & $\mathrm{N}$ & Death \\
\hline 17 & 45 & $\mathrm{~F}$ & ISM+ & 7.2 & + & PCR & $\mathrm{F}, \mathrm{CH}, \mathrm{M}$ & Home & $\mathrm{N}$ & $\mathrm{N}$ & recovery \\
\hline 18 & 76 & $\mathrm{M}$ & SM AHN & 82.1 & & $\begin{array}{l}\text { PCR, IgG/ } \\
\text { IgM }\end{array}$ & $\mathrm{F}, \mathrm{R}$ & Hosp & LF & $\mathrm{N}$ & recovery \\
\hline 19 & 60 & $\mathrm{M}$ & SM AHN & 30.6 & + & PCR & $\mathrm{C}, \mathrm{F}, \mathrm{M}, \mathrm{GI}$ & Hosp & LF & $\mathrm{N}$ & recovery \\
\hline 20 & 61 & $\mathrm{~F}$ & $\mathrm{CM}$ & 16.8 & + & PCR & $\mathrm{H}, \mathrm{M}, \mathrm{A}$ & Home & $\mathrm{N}$ & $\mathrm{N}$ & recovery \\
\hline 21 & 11 & $\mathrm{M}$ & $\mathrm{CM}$ & 18.3 & - & PCR & $\mathrm{C}, \mathrm{GI}, \mathrm{T}, \mathrm{M}$ & Home & $\mathrm{N}$ & $\mathrm{N}$ & recovery \\
\hline 22 & 16 & $\mathrm{M}$ & $\mathrm{CM}$ & 10.4 & + & IgM & $\mathrm{T}, \mathrm{H}, \mathrm{M}, \mathrm{A}$ & Home & $\mathrm{N}$ & $\mathrm{N}$ & recovery \\
\hline 23 & 39 & $\mathrm{~F}$ & $\mathrm{CM}$ & 13.5 & - & PCR & $\mathrm{F}, \mathrm{M}$ & Home & $\mathrm{N}$ & $\mathrm{N}$ & recovery \\
\hline 24 & 6 & $\mathrm{M}$ & $\mathrm{CM}$ & 6.8 & + & PCR & none & Home & $\mathrm{N}$ & $\mathrm{N}$ & recovery \\
\hline
\end{tabular}

${ }^{1}$ ISM: Indolent systemic Mastocytosis; ISM+: Indolent systemic mastocytosis with maculopapular cutaneous mastocytosis; CM: Cutaneous mastocytosis; HaT: Hereditary alpha tryptasemia; MCAS: Mast cell activation syndrome.

Viral symptoms. R: dyspnea, C: cough, F: fever, M: malaise/fatigue, H: headache, A: anosmia, GI: nausea/diarrhea, $\mathrm{CH}$ : chills, T: sore throat, $\mathrm{N}$ : rhinorrhea, D: dysgeusia

Oxygen requirement: LF: low flow nasal cannula, HF: high flow CPAP

"Denotes MCAS with elevated baseline serum tryptase 


\begin{tabular}{|l|l|l|l|l|l|l|l|l|l|l|l|}
\hline 25 & 51 & F & $\begin{array}{l}\text { H } \alpha \mathrm{T} \\
\alpha 2 \beta 3\end{array}$ & 18.6 & - & PCR & R, C, F, M & Hosp & LF & N & recovery \\
\hline 26 & 41 & F & MCAS $^{\text {a }}$ & 11.4 & - & PCR & C, F, T, N & Home & N & N \\
\hline 27 & 51 & M & MCAS $^{\text {a }}$ & 15.5 & - & IgG & $\begin{array}{l}\text { C, F, M, A, } \\
\text { GI, D }\end{array}$ & Home & N & recovery \\
\hline 28 & 58 & F & MCAS $^{\text {a }}$ & 26.4 & - & PCR & $\begin{array}{l}\text { C, F, H, } \\
\text { GI, N }\end{array}$ & Home & N & N \\
\hline
\end{tabular}

192

193

194

195

196 
199 Figure 1: Gene expression of ACE2, TLR3, and IL1RL1 on highly purified bone marrow mast cells from 200 normal/reactive $(\mathrm{n}=7)$ and systemic mastocytosis patients $(\mathrm{n}=26)$ from a 2013 study prior to the COVID20119 pandemic.

202 